\title{
DESIGN OF TRUSSES MADE OF CHANNEL SECTIONS ACCORDING TO EUROCODE RULES
}

\begin{abstract}
This paper presents research activity related to design of trusses made of channel sections according to Eurocodes. Roof trusses made of hot rolled channel sections are designed primarily for medium spans and relatively small loads. On the basis a method is proposed for the design of welds in $\mathrm{K}$ and $\mathrm{N}$ truss connections by using a method of effective lengths. Such welded joints should be design on the basis of the axial force in bracing. The layouts of the welds and the procedure for calculating the lengths of the weld are also proposed. In the case of intermediate joints of the top chord the shape of the joint with an insert made of channel used to fix braces to obtain their connection with sufficient resistance is suggested. A solution of support joints suitable for the direct arrangement of fillet welds connecting the top chord and first brace with the stubs made of square or rectangular hollow sections is also presented. Described methods enable to design of welded connections of trusses made of channel sections. These recommendations are valid for fillet or groove welded joints subjected to predominantly static loading.
\end{abstract}

Keywords: steel structures, $\mathrm{K}$ and $\mathrm{N}$ trusses joints, lengths of welds, resistance of members

\section{Introduction}

Roof trusses, made of hot rolled channel sections have many advantages compared to the same trusses made of angles or hollow sections. These advantages are:

a) The members of trusses are uniform as are the hollow sections, and they do not require connecting using lacings.

b) The connection of braces with the bottom chord does not require the use of gusset plates because the braces are connected directly to the side walls of the chord. In some design situations, in the case of the top chord,

\footnotetext{
${ }^{1}$ Jan Bródka, Bialystok University of Technology, jan.brodka@gmail.com

2 Author for correspondence: Mirosław Broniewicz, Bialystok University of Technology, ul. Wiejska 45E, 15-351 Białystok, tel. tel. 797995932, e mail: mrbron@gmail.com.
} 
especially when loaded by significant internal loads, the use of stiffening ribs made of plates or channels is necessary.

c) Modern polish steel construction factories are normally equipped with devices for cutting hot rolled open sections, allowing one to keep the angles and the length of the cut surfaces of the components as required by EN 1090-2 [12], but there is a lack of specialized devices for shaping the ends of hollow sections.

d) The connections of braces with chords are often made using fillet welds, and the simple shapes of joints greatly facilitate the performance of welds that are comparable to joints made of angles. The inclination of braces should not be less than $30^{\circ}$. In a few cases, it is necessary to use short butt welds.

e) The resistance of fillet welds is as great as that of butt welds, and ease of preparation of members for welding and the execution of fillet welds is much less onerous than in the case of butt welds.

f) As presented in paragraphs a) to e), preferred features result in a less laborious process to prepare the components of the trusses as compared to trusses, which are designed with angles. There is no need for cutting gusset plates and welding the chords in a U-shape or joining braces made of angles with lacings.

g) The price of hot rolled channel sections is significantly less than the price of hollow sections and is comparable with the cost of angles. The consumption of steel in a truss made of channel sections is, of course, greater than in the case of hollow sections and angles. However, the execution of the whole truss is at a much lower labour cost. This leads to more costeffective production [8].

The question arises as to why Polish designers so seldom use hot rolled channel sections in design, preferring lattice elements made of angles. The answer is as follows:

1. In universities, Polish engineers are seldom trained using a modern approach to design and do not taking into account the cost of construction. The long-known solution of trusses made of angles is preferred as they do not require more specialized knowledge as is the case with hollow sections, which, in Europe and in many other countries of the world, dominate roofing design.

2. Young engineers in their practice are dominated by the older generation of designers who are reluctant to introduce new solutions, usually because they require more work during the assessment of the capacity of the joints and their connections. Investors would like to have documentation quickly and at a low price, so the design studios are forced to use previously learned solutions.

3. The design guides have no indication regarding how to design and calculate trusses made of hot rolled channel sections, as, for example, noted 
in $[9,10,11,17,18,19]$. In a useful book [2], there is also no information regarding such joints. But the authors of this article are not without fault (see $[6,7])$.

4. The reason is that the joints of constructions made of hot rolled channel sections are mostly semi-rigid when they are designed according to the traditional approach. Designers, aware of this phenomenon, are afraid of using use them with the exception of closed sections obtained by welding two channel sections (see [4]).

5. In EN 1993-1-8 [14], information on joints made of channel sections are referred to only in the case in which chords are made of channels and braces are made of hollow sections. Recommendations to assess the resistance of such joints are, however, incomplete. A structurer in his professional career is forced to analyse a number of principles and rules, placed in different parts of Eurocode 3; however, some important issues are omitted or included in only a partial manner in the code.

6. Employees of Polish companies engaged in steel structures are more efficient than are most designers as domestic and foreign competition encourages them to use new technologies and approaches to the analysis of costs. But they are likely to use long-recognized design solutions, those with a higher consumption of material and which require more labour, because wages are still lower than in countries abroad, and conservation does not always lead to a reduction in the price of products.

The issues concerning the design of roof constructions made of hot rolled channel sections are largely related issues that are important in assessing the resistance of hollow structures. The author's proposals presented in this article use knowledge about the design and calculation of such elements $[5,6,7]$, especially in terms of their joints.

\section{General principles of design}

Roof trusses are made of steel grades as indicated in EN 10025 [16], chosen according to recommendations presented in EN 1993-1-10 [15]. Their members are designed according to EN 1993-1-1 [13] and their joints according to EN 1993-1-8 [14]. The designer should be aware that the principles and rules included in Eurocodes [13], [14] and [15], due to the admissibility of the simplifications adopted there, can be used only when the elements comply with the technical requirements of EN 1090-2 [12]. This basic principle of the reliability and safety of steel building structures is poorly emphasized in design standards. The designer should demand from the contractor that these requirements are strictly complied with as unacceptable deviations of structure assembling will decrease the resistance of the elements and their connections during the use of a building. 
Simple in shape tension connections, carrying the internal forces of truss members are more sensitive to failure to meet the technical requirements of EN 1090-2 [12] than are lap joints. These are generally semi-rigid joints, and wall deformation can be limited by designing a variety of stiffeners, but such treatments reduce the benefits of using channel sections, as mentioned in the beginning of this article. The effect of rigidity is considered during the calculation of the resistance of joints.

Roof trusses made of hot rolled channel sections are designed primarily for medium spans and relatively small loads due to the range of products manufactured in the country [3] as well as abroad [1]. Their scheme in static calculations can be considered as a system of members with pinned connections because the rigidity of channels in the plane of the truss is small, which means that there is no need to assess the chords as continuous members with attached brace members.

The layout of members in a truss suitable for welding is shown in Fig. 1.
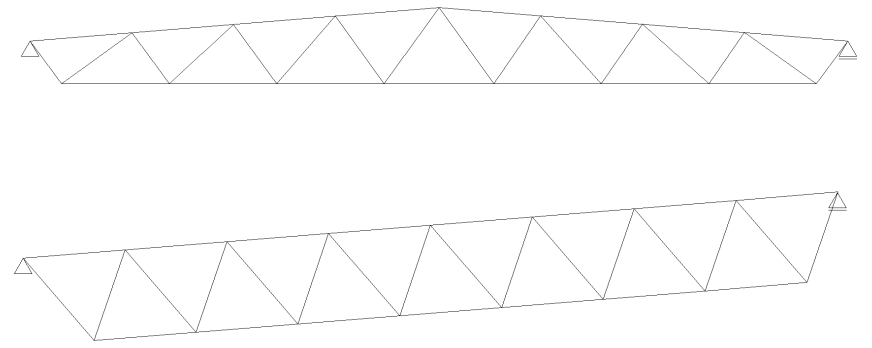

Fig. 1. Trusses suitable for welding

Rys. 1 Kratownice przeznaczone do spawania

The K-type joints should be designed in such way that the angles between the chords and the brace members are at least $30^{\circ}$. Then, access to the arrangement of the weld between the walls of the adjacent members is not too difficult. A sufficiently easy access also affects the distribution of channel sections applied on braces. The channels should not overlap each other, and trays should not allow the accumulation of dust and moisture. The formation of such disadvantages in K-type joints is prevented by designing the brace axis eccentrically to the axis of the chord.

Sections should be placed on the top of the web upward as both lower chords, which make it easy to design joints, and as top chords, which prevent the formation of elongated trays. Examples of the proper arrangement of braces are shown in Fig. 2 for the top and lower chords. In the latter design situation, it is necessary to include additional inserts. Designing a joint with large eccentriccity results in a low resistance of the joint and requires increased cross-sections. 
a)

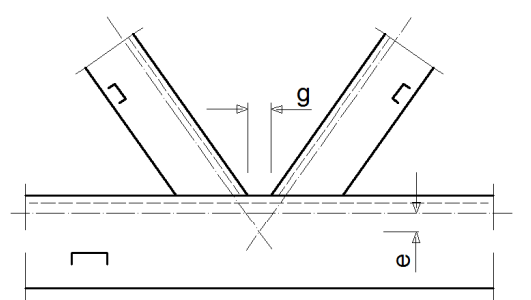

b)

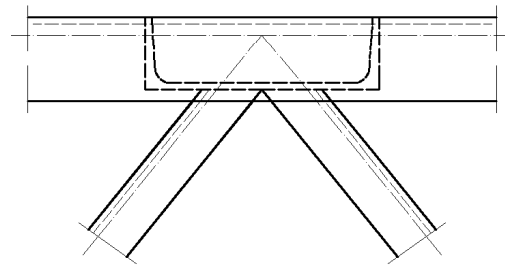

Fig. 2. Proper arrangement of braces in joints: a) the joint of a bottom chord, b) the joint of a top chord

Rys. 2 Właściwe ustawienie krzyżulców w węźle: a) węzeł pasa dolnego, b) węzeł pasa górnego

In the case of support joints, it is recommended to design the vertical post from hollow sections or a channel reinforced by the ribs. Other arrangements of braces, as indicated in Fig. 2, cause eccentricities that are too large in terms of their connection to the bottom chord and top joints that are too flexible, resulting in a need to design the ribs and inconvenient welding.

The gap between the braces in the bottom chord or between the brace and the web of the top chord should allow for the easy setting of fillet welds. Examples of determining the minimum gap are shown in Fig. 3. Dimension $g$ according to EN1993-1-8 [14] is at least $t_{1}+t_{2}$, where $t$ is the thickness of the braces.

a)

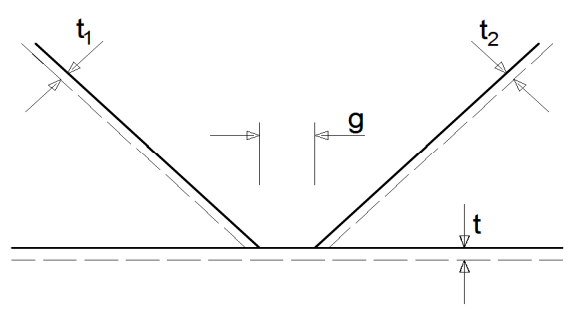

b)

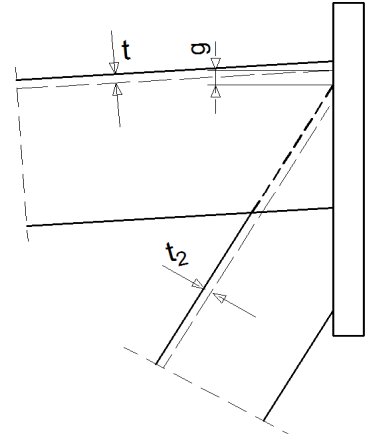

Fig. 3. Gaps between the braces: a) the bottom chord, b) the splice joint Rys. 3 Odstęp między krzyżulcami: a) w pasie dolnym, b) w styku wiązara 
The paper does not discuss the assessment of the resistance of truss members as this is commonly known and conducted according to the principles and rules contained in EN 1993-1-1 [13] concerning the tension and compression of members when taking into consideration the possibility of buckling and bending. The hot rolled channels specified in steel shapes databases [1] and [3] are generally not prone to lateral torsional buckling or local buckling and distortion of the walls of the joint since such large local loads do not occur in average span trusses.

Designed eccentrics should be considered during assessing tension or compression design resistance. A method of evaluating the bending moments, which arise in the chord when the axes of the braces do not intersect at one point with the axis of the chord is given in design books [6,7], assuming that such members have simple connections.

\section{The joints of the bottom chord}

\subsection{The resistance of the connection}

Fig. 4 shows the shape of the joint loaded by longitudinal force $K_{i}$ and dimensions of the components of braces and welds. A layout of the designed cross sections of the welds is shown in Fig. 5. The welds are loaded with components of the forces parallel to the chord $K_{j} \cos \theta_{j}$ and perpendicular to the chord $K_{j} \sin \theta_{j}$, where $\theta_{j}$ is the angle of inclination of the axis of the ace to the axis of the chord.

In the case of the second brace in the joint (Fig. 2), with the angle of inclination to the chord $\theta_{i}$, which is loaded by the longitudinal force $K_{i}$, the design procedure is as follows. The stresses should be assessed similarly, but their values are considered at a new load and with changing the load mark from compression to tension.

To simplify the procedure further and to evaluate the stresses in the individual lengths of the fillet welds, their symbols and lengths are determined in the case when the gap between the webs is not less than $t_{1}+t_{2}$ (where $t_{1}$ and $t_{2}$ are the thicknesses of webs), but the individual lengths of the welds should not exceed the values:

$$
l_{1}=h_{j} / \sin \theta_{j} ; l_{2}=l_{1}-\left(t_{w j}+r_{i j}\right) ; l_{3}=b_{j} ; \quad l_{4}=l_{3}-2\left(t_{f j}+r_{j j}\right) ;
$$

where: $b_{j}$ - the height of the chord channel,

$h_{j}$ - the width of the chord channel,

$t_{f j}$ - the web thickness of the brace,

$t_{w j}$ - the flange thickness of the brace,

$r_{j j}$ - the radius between the web and the flange of the brace,

$\theta_{j}-$ the angle of brace in relationship to the chord. 

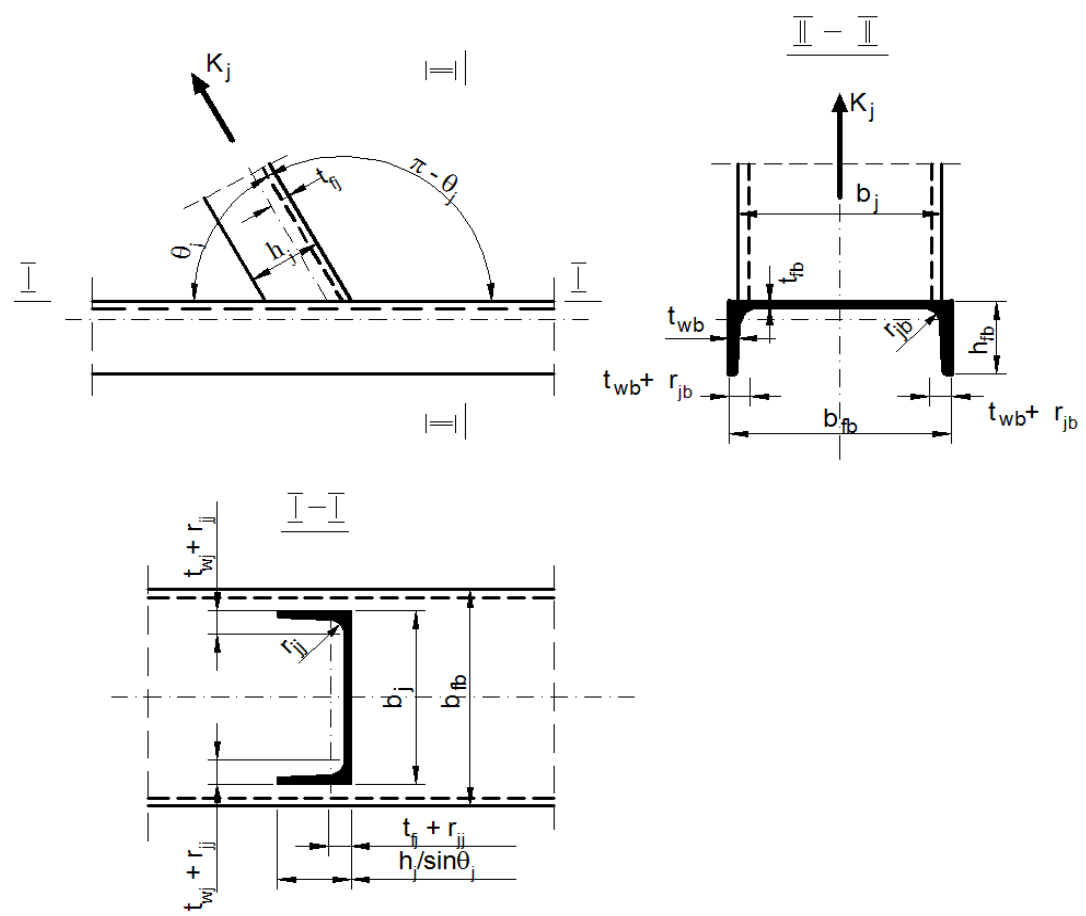

Fig. 4. Joint made of channel sections

Rys. 4 Węzeł wykonany z kształtowników ceowych

Fig. 5 shows the components $P_{1}^{\prime}$ to $P_{4}^{\prime}$ transmitted through the individual lengths of the welds in terms of the force parallel to the chord $K_{j} \cos \theta_{j}$. In the same figure, dots on the lengths of welds show the points of applying forces $P_{1}$ " to $P_{4}$ " of the component perpendicular to the chord $K_{j} \sin \theta_{j}$.

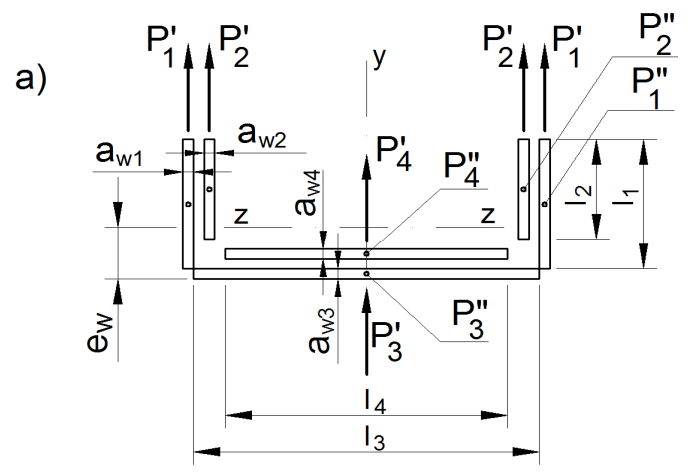

Fig. 5. Layout of welds

Rys. 5 Układ spoin 
In the case of pinned connections of the braces with the chord, these forces are determined as follows:

$$
\begin{aligned}
& A_{1}=l_{1} a_{w 1} ; \quad A_{2}=l_{2} a_{w 2} ; \quad A_{3}=l_{3} a_{w 3} ; \quad A_{4}=l_{4} a_{w 4} ; \\
& \sum A=2\left(A_{1}+A_{2}\right)+A_{3}+A_{4}, \\
& P_{1}^{\prime}=A_{1} K_{j} \cos \theta_{j} / \sum A, \quad P_{2}^{\prime}=A_{2} K_{j} \cos \theta_{j} / \sum A, \\
& P_{3}^{\prime}=A_{3} K_{j} \cos \theta_{j} / \sum A, \quad P_{4}^{\prime}=A_{4} K_{j} \cos \theta_{j} / \sum A .
\end{aligned}
$$

The individual thicknesses of the welds should be so set that the sum of the resistances of welds $l_{1}$ and $l_{2}$ or $l_{3}$ and $l_{4}$ is not larger than the resistance of suitable walls.

The distribution of the force perpendicular to chord $K_{j} \sin \theta_{j}$ between each length of the welds is done by equation (4), replacing the function $\cos \theta_{j}$ by $\sin \theta_{j}$.

The centre of gravity of the welds does not coincide with the centre of gravity of a section of the brace. The formed eccentricity creates a bending moment derived from the component $K_{j} \sin \theta_{j}$. It is determined as follows:

$$
e=e_{w}-e_{k} / \sin \theta_{j},
$$

where: $e_{w}$ - the distance of the centre of gravity of the welds from the outer edge of the web of the brace,

$e_{k}$ - the distance of the centre of gravity of the brace from the outer edge of the web of the brace.

This moment causes stresses $\sigma_{M}$ on edges of the welds that act as force $P_{I}$ " to $P_{4}$ ". The values of these stresses are determined in accordance with the principles of structural mechanics according to the relationship:

$$
\sigma_{M}=M_{k} \cdot z / I_{z w},
$$

in which: $M_{k}=e K_{j} \sin \theta_{j}$,

$z$ - the distance of the extreme fibre of the analysed length of the weld from the neutral axis,

$I_{z w}$ - the moment of inertia of the layout of all lengths of welds from the neutral axis.

Fig. 6 shows cross-sections of welds $l_{1}$ and $l_{2}$. The stresses in the crosssection of weld $l_{1}$ are:

- the load parallel to the chord $K_{j} \cos \theta_{j}$ (Fig. 6a):

$$
\sigma^{\prime}=0, \quad \sigma_{\perp}^{\prime}=\tau_{\perp}^{\prime}=0, \quad \tau_{\|}^{\prime}=P_{1}^{\prime} / A_{1},
$$

- the load perpendicular to the chord $K_{j} \sin \theta_{j}$ and bending moment (Fig. 6b):

$$
\sigma^{\prime \prime}=P_{1}^{\prime \prime} / A_{1}+\sigma_{M 1}, \quad \sigma_{\perp}^{\prime \prime}=\tau_{\perp}^{\prime \prime}= \pm \sigma^{\prime \prime} / \sqrt{2}, \quad \tau_{\|}^{\prime \prime}=0 \text {. }
$$


a)

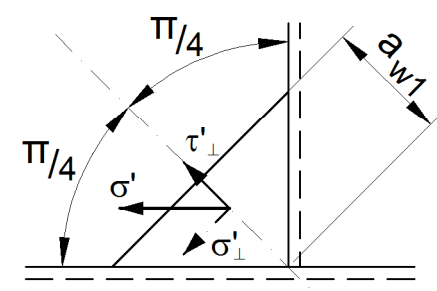

b)

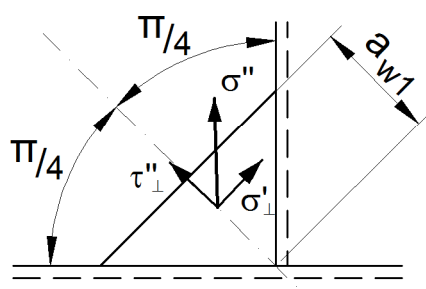

Fig. 6. Stresses in the cross-section of welds $l_{1}$ and $l_{2}$

Rys. 6 Naprężenia w przekroju poprzecznym spoin $l_{l}$ i $l_{2}$

The stresses in the design section of weld $l_{2}$ are calculated by equation (7) (Fig. 6a) changing $P_{1}^{\prime \prime}$ to $P_{2}^{\prime \prime}, A_{1}$ to $A_{2}$ and taking into account $\sigma_{M 2}$.

Fig. 7 shows cross-sections of welds $l_{3}$ and $l_{4}$. The stresses in the crosssection of weld $l_{3}$ are:

- the load parallel to the chord (Fig. 7a):

$$
\sigma^{\prime}=P_{3}^{\prime} / A_{3}, \sigma_{\perp}^{\prime}=-\sigma^{\prime} \cos \left(\theta_{j} / 2\right), \tau_{\perp}^{\prime}=-\sigma^{\prime} \sin \left(\theta_{j} / 2\right), \tau_{\|}^{\prime}=0 .
$$

- the load perpendicular to the chord and bending moment (Fig. 7b):

$$
\sigma^{\prime \prime}=P_{3}^{\prime \prime} / A_{3}+\sigma_{M 3}, \sigma_{\perp}^{\prime \prime}=-\sigma^{\prime \prime} \sin \left(\theta_{j} / 2\right) \cdot \tau_{\perp}^{\prime \prime}=\sigma^{\prime \prime} \cos \left(\theta_{j} / 2\right), \tau_{\|}^{\prime \prime}=0 \text {. }
$$

a)

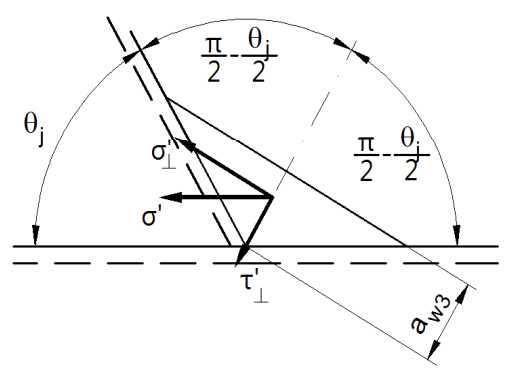

b)

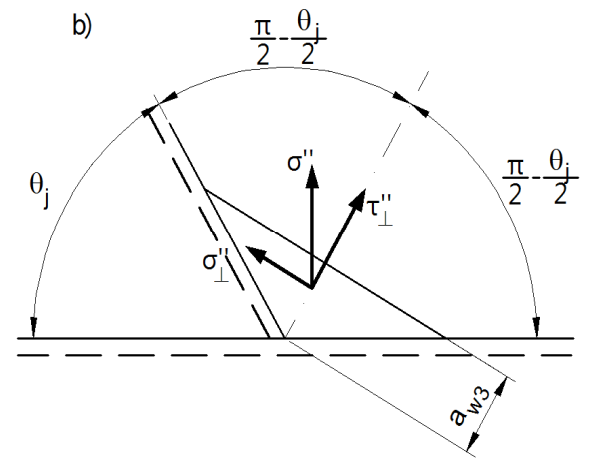

Fig. 7. Stresses in the cross-section of weld $l_{3}$ and $l_{4}$

Rys. 7 Naprężenia w przekroju poprzecznym spoin $l_{3}$ i $l_{4}$ 
Fig. 8 shows the cross-section of weld $l_{4}$. The stresses in the weld are: - the load parallel to the chord (Fig. 8a):

$$
\sigma^{\prime}=P_{4}^{\prime} / A_{4}, \sigma_{\perp}^{\prime}=-\sigma^{\prime} \sin \left(\theta_{j} / 2\right), \tau_{\perp}^{\prime}=-\sigma^{\prime} \cos \left(\theta_{j} / 2\right), \tau_{\|}^{\prime}=0 .
$$

- the load perpendicular to the chord (Fig. 8b):

$$
\sigma^{\prime \prime}=P_{4}^{\prime \prime} / A_{4}+\sigma_{M 4}, \sigma_{\perp}^{\prime \prime}=\sigma^{\prime \prime} \cos \left(\theta_{j} / 2\right), \tau_{\perp}^{\prime \prime}=-\sigma^{\prime \prime} \sin \left(\theta_{j} / 2\right), \tau_{\|}^{\prime \prime}=0 .
$$

To check the resistance of the joint components of the stresses, the individual lengths of welds should be added together:

$$
\sigma_{\perp}=\sigma_{\perp}^{\prime}+\sigma_{\perp}^{\prime \prime}, \quad \tau_{\perp}=\tau_{\perp}^{\prime}+\tau_{\perp}^{\prime \prime}, \quad \tau_{\|}=\tau_{\|}^{\prime}+\tau_{\|}^{\prime \prime} .
$$

Then, apply the directional method according to EN 1993-1-8 [14].
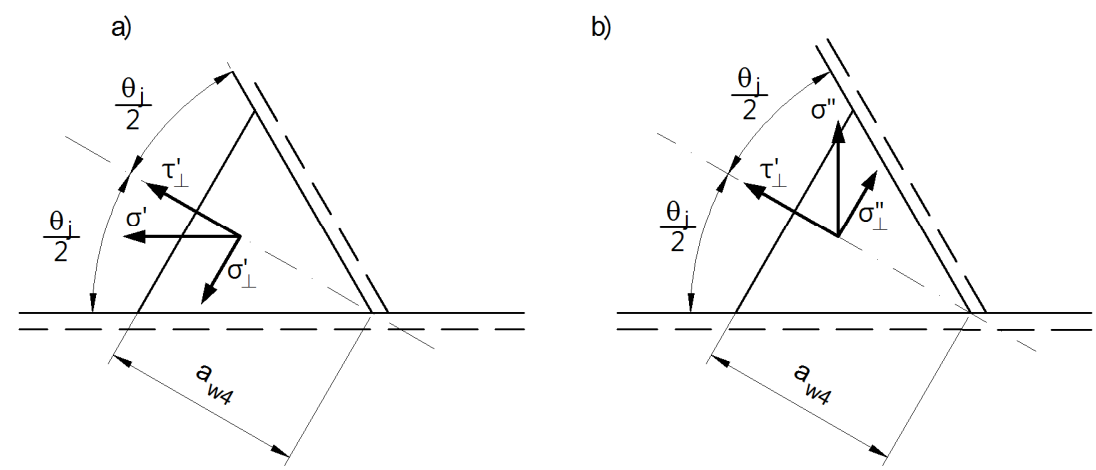

Fig. 8. Stresses in the cross-section of weld $l_{4}$

Rys. 8 Naprężenia w przekroju poprzecznym spoiny $l_{4}$

The greatest stress in one of the concerned sections of the welds indicates the resistance of the joint.

In the connection of the brace with the bottom chord shown in Fig. 2a), the weld $l_{3}$ is making contact with adjacent walls at an angle $\theta_{j}>120^{\circ}$.

In EN 1993-1-8 [14], checking the resistance of such a weld is in accordance with the Annex to PN-EN 1090-2 [12]. Customarily, during fabrication, the conversion of such a fillet weld to a butt or groove weld is done, but, in calculation, such a weld is treated as a fillet weld. In Fig. 9, such a fillet weld is shown with the thickness $a_{w 3}=t_{w j} \leq t_{w b}\left(t_{w b}\right.$ - the thickness of the chord web). With this arrangement, weld $l_{4}$ does not occur at all because, in that place, 
welding of the groove weld only is done, and, in formula (2), the calculated thickness is taken as $a_{w 4}=0$.

The stresses in the cross-section of groove weld $l_{3}$ (Fig. 9) are:

- the load parallel to the chord:

$$
\begin{aligned}
& \sigma^{\prime}=P_{3}^{\prime} / A_{3}, \sigma_{\perp}^{\prime}=-\sigma^{\prime} \sin (\pi / 6)=-0,5 \sigma^{\prime}, \\
& \tau_{\perp}^{\prime}=-\sigma^{\prime} \cos (\pi / 6)=-0,866 \sigma^{\prime}, \tau_{\|}^{\prime}=0 .
\end{aligned}
$$

- the load perpendicular to the chord:

$$
\begin{aligned}
& \sigma^{\prime \prime}=P_{3}^{\prime \prime} / A_{3}+\sigma_{M 3}, \sigma_{\perp}^{\prime \prime}=-\sigma^{\prime \prime} \cos (\pi / 6)=-0,866 \sigma^{\prime \prime}, \\
& \tau_{\perp}^{\prime \prime}=\sigma^{\prime \prime} \sin (\pi / 6)=0,5 \sigma^{\prime \prime}, \tau_{\|}^{\prime \prime}=0 .
\end{aligned}
$$

When calculating the stress components, the eccentricity $t_{f j} / 6$ between the axial application of force $K_{j}$ and $\sigma_{\perp}$ as the small value are omitted.

a)

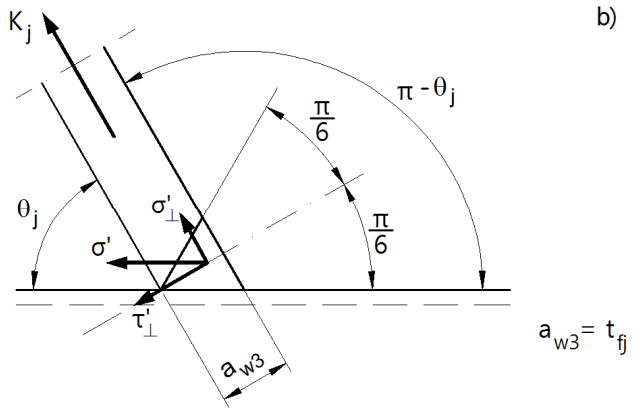

b)

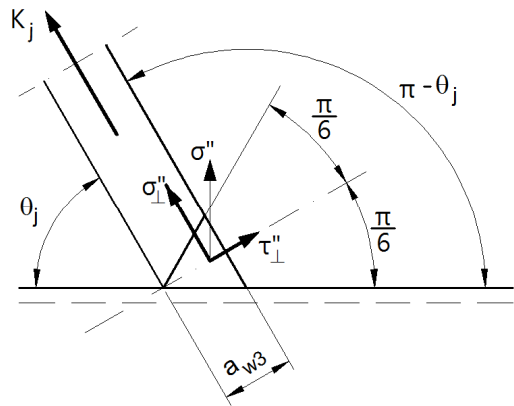

Fig. 9 Stresses in the cross-section of groove weld $l_{3}$

Rys. 9 Naprężenia w przekroju poprzecznym spoiny czołowej $l_{3}$

In small or mid-span roof trusses, the top and bottom chord are an unchanged cross-section, whereas the cross-section of braces is adapted to the longitudinal forces, but, due to cost-effective inventory management during the fabrication of such trusses, only two different sections of the braces are designed. In the described type of truss, the change of the brace cross section is made in the joint of the bottom chord because, if done to the top chord, it would lead to a very complicated joint shape. 


\subsection{The resistance of the members}

In addition to checking the connection between the braces and the chord, the resistance of the members must be also checked.

The destruction of a brace occurs in the case of achieving the value:

$$
K_{j . R d}=A_{j} f_{y j} / \gamma_{M 5} \geq K_{j}
$$

where: $A_{j}-$ the cross-section area of the brace,

$f_{y j}-$ the yield strength of the brace.

However, in relation to the bottom chord, it should be considered that:

- destruction of the channel flanges of force $K_{j} \sin \theta_{j}$ is due to shear:

$$
K_{j . R d}=\frac{A_{v} f_{y b}}{\sqrt{3} \sin \theta_{j} \cdot \gamma_{M 5}} \geq K_{j},
$$

- destruction of the entire cross-section of the chord:

$$
N_{0 . R d}=\left[A_{0}-A_{v}+A_{v} \sqrt{1-\left(V_{E d} / V_{p l . R d}\right)^{2}}\right] f_{y b} / \gamma_{M 5},
$$

where: $A_{0}$ - the cross-section area of the chord,

$A_{v}$ - the design area of the cross-section of the chord flanges,

$$
A_{v}=A_{0}-\left(1-\alpha_{0}\right)\left[b_{f b}-2\left(t_{w b}+r_{j b}\right)\right\rfloor t_{w b},
$$

$f_{y b}$ - the yield strength of the chord

$V_{E d}=K_{j, E d} \sin \theta_{j}=K_{j} \sin \theta_{j}-$ the transverse force loading the chord in the joint,

$$
\begin{aligned}
& V_{p l . R d}=A_{v} f_{y b} /\left(\sqrt{3} \gamma_{M 5}\right), \\
& \alpha_{0}=\sqrt{\frac{1}{1+\frac{4}{3}\left(\frac{g}{t_{w b}}\right)^{2}}} \quad \begin{array}{l}
\text { - the reducing coefficient of the chord web, } \\
\text { of thection }
\end{array}
\end{aligned}
$$

$g$ - the gap between webs of braces,

$t_{w b}-$ the thickness of the chord flange,

$\gamma_{M 5}=1,0$ - the partial safety factor related to the chord. 


\section{Intermediate joints of the top chord}

\subsection{The resistance of the joint}

Fig. 10 shows the shape of the joint of the top chord with an insert made of a channel generally used on braces. This insert is used to fix the braces to obtain their connection with sufficient resistance and in a way that is suitable for welding. Fig. 11 shows the layout of the forces loading the insert and the dimensions of lengths of welds joining the insert with the braces, used to determine the effective length of weld $l_{l}$ :

$$
\begin{aligned}
& \Delta_{i, 1}=\left(h_{c h}+t_{f b}-e_{z b}\right) \tan \left(\pi / 2+\alpha-\theta_{i}\right), \quad \Delta l_{j, 1}=\left(h_{c h}+t_{f b}-e_{z b}\right) \tan \left(\pi / 2-\alpha-\theta_{i}\right), \\
& \Delta l_{i, 2}=e_{z i} / \sin \left(\theta_{i}-\alpha\right), \Delta l_{j, 2}=e_{z j} / \sin \left(\theta_{i}+\alpha\right), \\
& l_{1}=\Delta l_{i, 1}+\Delta l_{i, 2}+\Delta l_{j, 1}+\Delta l_{j, 2},
\end{aligned}
$$

where: $h_{c h}-$ the flange width of the insert made of the channel,

$t_{f b}$ - the web thickness of the insert made of the channel,

$\alpha$-the angle of inclination of the top chord in relation to the bottom chord,

$e_{z b}$ - the distance of the centre of gravity of the cross-section of the top chord from the outer edge of its web,

$e_{z i}$ - the distance of a centre of gravity of the cross-section of the brace from the outer edge of its web (in the joints of the top chord, the braces of the same cross-section are designed),

$\theta_{i}$ - the angle of the inclination of the brace loaded by force $K_{i}$ in relation to the bottom chord.

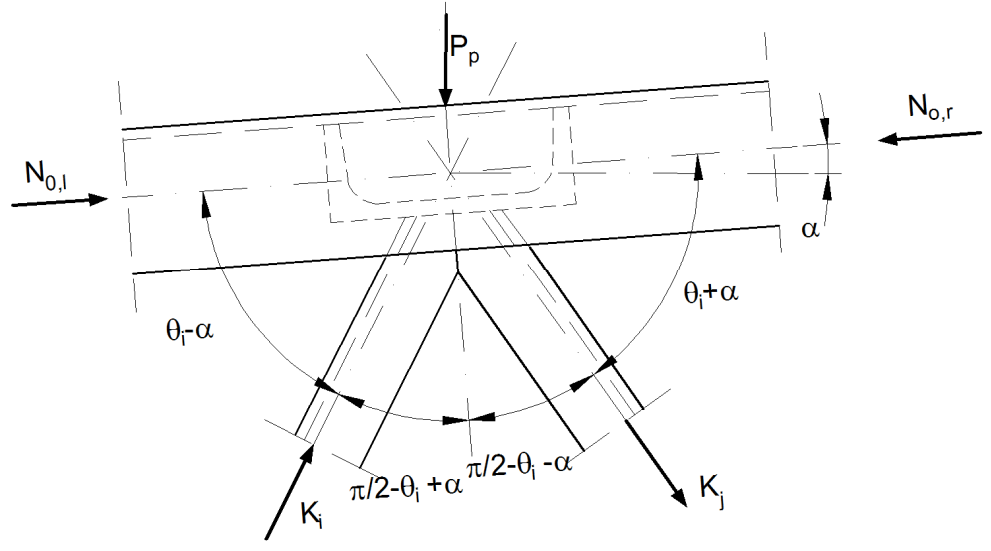

Fig. 10 Joint of the top chord with an insert

Rys. 10 Węzeł pasa górnego z wkładką 
The other lengths of the welds are as follows:

$$
l_{2}=l_{1}-2\left(t_{f j}+r_{j j}\right) ; \quad l_{3}=b_{i}=b_{j} ; \quad l_{4}=l_{3}-2\left(t_{w j}+r_{j j}\right) .
$$

The thickness of the fillet weld is determined in the manner indicated for the joints of the bottom chord. This is estimated by taking into account the wall thickness of the insert and the braces.

In addition, there is weld $l_{5}$ in this joint connecting the flanges of the braces. The length of weld $l_{5}$ can be determined as:

$$
l_{5}=\frac{\left(h_{i}-e_{z i}\right)}{\cos \theta_{i}}+e_{z b}-t_{f b}-h_{c h}, a_{w 5}=t_{w i}
$$

but

$$
h_{i}=h_{j} \text { and } t_{w i}=t_{w j},
$$

(see the symbols of the bottom chord).

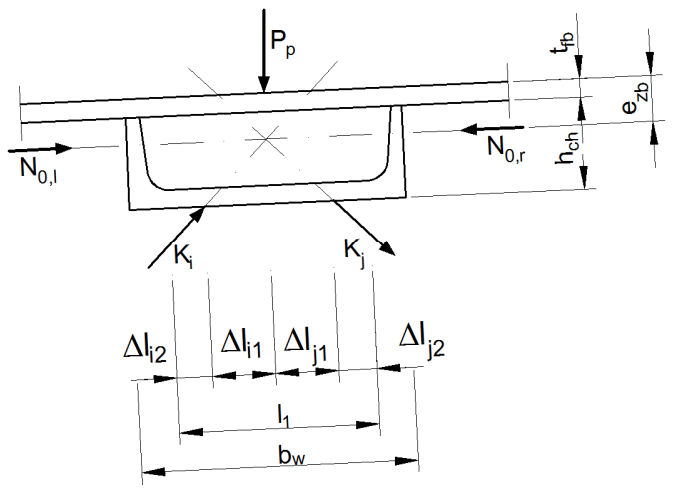

Fig. 11 Layout of the forces loading the insert

Rys. 11 Układ sił obciążających wkładkę

Weld $l_{5}$ is inclined from an axis perpendicular to the web of the insert by angle $\alpha$. At a low slope of the roof $(1: 20$ to $1: 10)$ the difference in deflection is about $0.5 \%$ to $1.5 \%$. This difference is omitted, assuming the indicated length of weld $l_{5}$.

Figure 12 shows the component forces transmitted through the lengths of welds from the resultant force $K_{i} \cos \left(\theta_{i}-\alpha\right)+K_{j} \cos \left(\theta_{i}+\alpha\right)$ parallel to the web of the insert, designated as $P_{1}{ }^{\prime}$ to $P_{5}{ }^{\prime}$, and from the resultant force $K_{i} \sin \left(\theta_{i}-\alpha\right)-K_{j} \sin \left(\theta_{i}+\alpha\right)$ perpendicular to this element, designated as $P_{l}^{\prime \prime}$ do $P_{5}$ ". With regard to these forces, their location on the welds is indicated with dots in Fig. 12. 


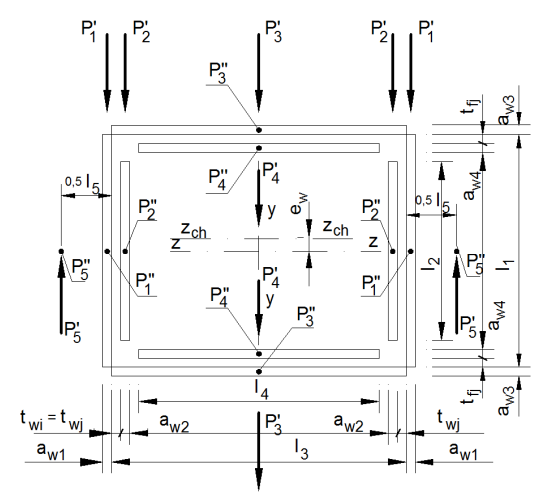

Fig. 12 Component forces transmitted through the lengths of welds

Rys. 12 Składowe sił przenoszonych przez poszczególne ściegi spoin

Assuming the pinned connections of the braces in the joint with the insert, these forces are determined as follows.

The cross-section areas of the individual welds are determined from equations (2) adding $A_{5}=l_{5} a_{w 5}$. Then the total cross-sectional area is as follows:

$$
\sum A=2\left(A_{1}+A_{2}+A_{3}+A_{4}+A_{5}\right) .
$$

Forces in welds parallel to the web of the insert are calculated using formula (4), adopting instead of $K_{j}$ the value of the corresponding resultant force and instead of $\theta_{i}$ the angle $\left(\theta_{i}+\alpha\right)$, further supplemented with $P_{5}^{\prime}$.

Next, the division of the resultant force perpendicular to the web insert is made by formula (4), assuming that force instead of $K_{j} \cos \theta_{i}$ and changing the angle of inclination. This is further supplemented with $P_{5}{ }^{\prime}$.

The resultant force $K_{i} \cos \left(\theta_{i}-\alpha\right)+K_{j} \cos \left(\theta_{i}+\alpha\right)$ acts on the eccentricity:

$$
e=h_{c h}+t_{f b}-e_{z b}-0,5 t_{w c h},
$$

where $t_{w c h}$ is the thickness of the web of the channel insert. A bending moment is formed acting on the stress state in the design sections of welds as well as the forces $P_{1}^{\prime \prime}$ to $P_{4}^{\prime \prime}$.

In contrast, the resultant force $K_{i} \sin \left(\theta_{i}+\alpha\right)-K_{j} \sin \left(\theta_{i}+\alpha\right)$ acts on an eccentricity, which is determined as the shift of the centre of gravity of the weld layout in relation to the centre of gravity of the cross section of the insert. This can be expressed as the following equation:

$$
e_{c h}=e\left[c \tan \left(\theta_{i}-\alpha\right)-c \tan \left(\theta_{i}+\alpha\right)\right]+\frac{e_{z i}\left[\sin \left(\theta_{i}+\alpha\right)-\sin \left(\theta_{i}-\alpha\right)\right]}{\left[\sin \left(\theta_{i}+\alpha\right) \cdot \sin \left(\theta_{i}-\alpha\right)\right]} .
$$


The stresses $\sigma_{M}$ on the edges of sections are determined according to formula (6), where:

$$
\left.M_{k}=e\left\{K_{i} \cos \left(\theta_{i}-\alpha\right)+K_{j} \cos \theta_{i}+\alpha\right)+\left[K_{i} \sin \left(\theta_{i}-\alpha\right)-K_{j} \sin \left(\theta_{i}+\alpha\right)\right] \tan (2 \alpha)\right\} .
$$

Stress components $\sigma_{\perp}^{\prime}, \tau_{\perp}^{\prime}, \tau_{\|}^{\prime}$ and $\sigma_{\perp}^{\prime \prime}, \tau_{\perp}^{\prime \prime}, \tau_{\|}^{\prime \prime}$ are calculated in the crosssections of individual welds under the forces $P_{1}{ }^{\prime}$ to $P_{5}{ }^{\prime}$ and $P_{1}{ }^{\prime \prime}$ to $P_{5}{ }^{\prime \prime}$ using formulas (7) to (9), and the resistance of the joint is checked as in the case of the lower joint.

The channel insert transfers the load from the braces, loaded by the forces $K_{i}$ and $K_{j}$, on the two welds connecting their flanges with the top chord. The load of this layout of the welds is:

-the resultant forces in the braces parallel to the chord:

$$
K_{i} \cos \left(\theta_{i}-\alpha\right)+K_{j} \cos \left(\theta_{i}+\alpha\right)
$$

-the resultant forces in the braces perpendicular to the chord:

$$
K_{i} \sin \left(\theta_{i}-\alpha\right)-K_{j} \sin \left(\theta_{i}+\alpha\right),
$$

-the bending moment causing the stresses $\sigma_{M}$ in the welds, acting similarly to the resultant force perpendicular to the chord.

The eccentricity is expressed as the following equation:

$$
e_{k}=e_{z b}-t_{w b},
$$

and the bending moment is equal to:

$$
M_{k}=e_{k}\left\lfloor K_{i} \cos \left(\theta_{i}-\alpha\right)+K_{j} \cos \left(\theta_{i}+\alpha\right)\right] .
$$

The indicated bending moment causes the stresses in the weld is expressed as:

$$
\sigma_{M}=\frac{M_{k}}{a_{w} l_{c, c h}\left(b_{c h}+\frac{4}{3} \sqrt{2} a_{w}\right)},
$$

where: $a_{w}-$ the thickness of the weld joining the flange of the insert with the top chord,

$l_{c . c h}=b_{f b}-2\left(t_{f b}+r_{j b}\right)$ - the length of the weld joining the flange of the insert with the top chord,

$b_{c h}$ - the height of the channel used on the insert. 
The meanings of the symbols in the formula for $l_{c . c h}$ are explained earlier, but now they must be adopted in relation to the cross-section of the top chord.

Stress components in the design cross-sections of welds shall be determined as follows:

$$
\begin{aligned}
& \sigma^{\prime}=\frac{K_{i} \cos \left(\theta_{i}-\alpha\right)+K_{j} \cos \left(\theta_{i}+\alpha\right)}{2 a_{w} l_{c . c h}}, \sigma_{\perp}^{\prime}=\tau_{\perp}^{\prime}= \pm \sigma^{\prime} / \sqrt{2}, \tau_{\|}^{\prime}=0, \\
& \sigma^{\prime \prime}=\frac{K_{i} \sin \left(\theta_{i}-\alpha\right)-K_{j} \sin \left(\theta_{i}+\alpha\right)}{2 a_{w} l_{c . c h}}+\sigma_{M}, \sigma_{\perp}^{\prime}=\tau_{\perp}^{\prime}= \pm \sigma^{\prime} / \sqrt{2}, \tau_{\|}^{\prime \prime}=0,
\end{aligned}
$$

where $\sigma_{M}$ is according to formula (28).

Checking the resistance of the joint is carried out using the directional method given in EN 1993-1-8 [14]:

$$
\begin{aligned}
& {\left[\sigma_{\perp}^{2}+3\left(\tau_{\perp}^{2}+\tau_{I I}^{2}\right)\right] \leq f_{u} /\left(\beta_{w} \gamma_{M 2}\right),} \\
& \sigma_{\perp} \leq 0,9 f_{u} / \gamma_{M 2},
\end{aligned}
$$

where: $\beta_{w}-$ is the correlation factor of fillet welds,

$f_{u}$ - is the nominal ultimate tensile strength of steel,

$\gamma_{M 2}=1,25$ is the safety factor.

The channel insert is connected to the top chord using the layout of welds shown in Fig. 13. These welds are loaded by resultant forces according to equations (18) and (19) and the bending moment according to (21). There are two such layouts of welds, so each of them is calculated under a twice-smaller load. Checking the resistance of the connection may be done using the directional method described in the present article.
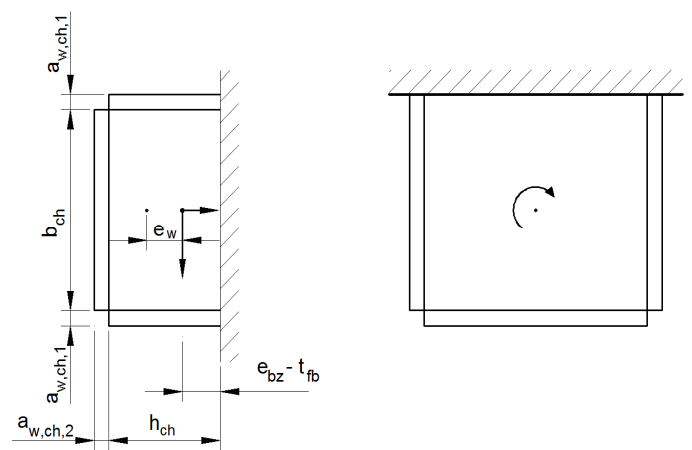

Fig. 13 Layout of welds joining the channel insert with the top chord Rys. 13 Układ spoin łączących wkładkę z ceownika z pasem górnym 


\subsection{The resistance of the members in the joint}

The resistance of the braces is sufficient since their longitudinal forces are smaller than the force in the first support brace, and the resistance of that brace was calculated in section 3.2 with the same cross-sections.

The destruction of the top chord is analysed according to formulas presented in the case of the bottom chord:

- the destruction of the flange loaded by the force $K_{j} \sin \left(\theta_{i}-\alpha\right)$ or $K_{i} \sin \left(\theta_{i}+\alpha\right)$, where $K_{j}$ is the longitudinal force of the brace on the right hand side of the joint according to eq. (13),

- the destruction of the entire cross-section of the chord under complex load according to eq. (14), where $\alpha_{0}=0$.

The capacity of the channel insert is verified by assessing the capacity of the T-type joint according to the equations presented in Table 7.14 in EN 1993-1-8 [14] under the resultant load perpendicular to the web of the insert including the bending moment. It can be expressed as:

$$
\frac{N_{i . E d}}{N_{i . R d}}+\left|\frac{M_{i . E d}}{M_{i . R d}}\right|^{2} \leq 1, \text { wherein } V_{E d} \leq 0,5 V_{p l . R d},
$$

where: $N_{i . E d}=K_{i} \sin \left(\theta_{i}-\alpha\right)-K_{j} \sin \left(\theta_{i}+\alpha\right)$,

$N_{i, R d}$ - the design axial resistance of the joint according to Table 7.11 in PN-EN 1993-1-8 [14],

$M_{i, E d}=M_{k}$ according to Eq. (23),

$M_{i, R d}$ - the design resistance moments according to Table 7.11 in PN-EN 1993-1-8 [14] in case of a rectangular cross-section with dimensions $l_{i} \times b_{i}$ and a wall thicknesses $t_{f i}$ and $t_{w i}$,

$$
\begin{aligned}
& V_{E d}=K_{i} \cos \left(\theta_{i}-\alpha\right)+K_{j} \cos \left(\theta_{i}+\alpha\right), \\
& V_{p l . R d}=\frac{A_{v} \cdot\left(f_{y} / \sqrt{3}\right)}{\gamma_{M 0}} .
\end{aligned}
$$

On the other hand, the capacity of the bottom chord under a load of purlins $P_{p}$ in the section above the insert is checked as in the case of the bottom chord, taking longitudinal force $N_{0}$, reduced by the value $K_{j} \cos \left(\theta_{i}+\alpha\right)$, according to the formulas relating to the gusset plate arranged transversely in Table 7.13 in EN 1993-1-8 [14]. The strain effects of the insert should be summarized. 


\section{The support joint}

\subsection{The shaping of support joints}

Figs. 14 and 15 show a solution suitable for the direct arrangement of fillet welds connecting the top chord and first brace with the stubs of support joints. The shape of the K-type joint is adapted to the geometry of the lattice structure based on a steel or reinforced concrete column and possibly also a wall.

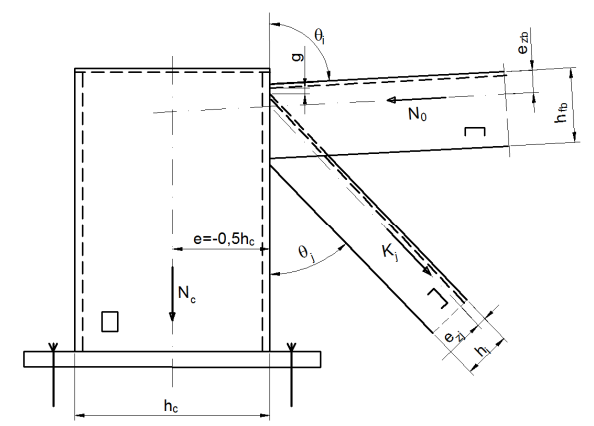

Fig. 14 Support joint with the stub made of hollow section

Rys. 14 Węzeł podporowy z króćcem wykonanym z kształtownika rurowego

The geometry of the truss shown in Fig. 1 enables convenient, direct connecting of the walls of truss members as the relative angles of inclination of the members are mostly about $40^{\circ}$.

For the stubs in the level of the top chord, square or rectangular hollow sections or channels with ribs strengthening their flanges are used. However, in the second design situation, it is sometimes necessary to strengthen the web of the channel section by means of a plate welded to the wall.

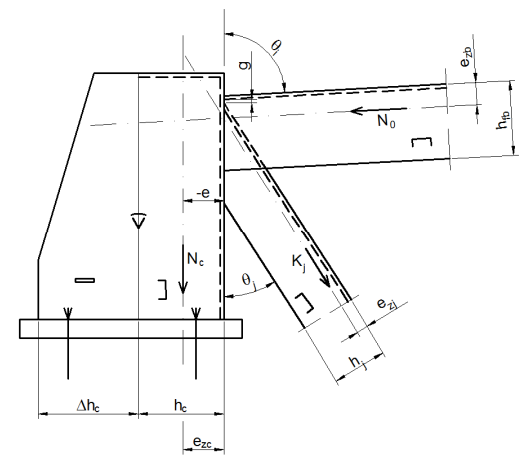

Fig. 15 Support joint with the stub made of a channel section with a rib Rys. 15 Węzeł podporowy $\mathrm{z}$ króćcem wykonanym z ceownika $\mathrm{z}$ użebrowaniem 
The brace is arranged a small distance from the top chord so that the gap is a little more than $g=t_{1}+t_{2}$ (where $t_{1}$ and $t_{2}$ - thickness of the webs of the braces and the top chord). This makes the brace situated relative to the support member with a large negative eccentricity. Such a geometric arrangement allows treating the joint as type $\mathrm{K}$. In the illustrated solution, the stub becomes a chord, and the brace and the top chord in the interpretation indicated in EN 1993-1-8 [14] become the braces. It is not recommended to design a large gap $g$ because the support joint would be then considered as two independent Y-type joints. Doing so, the capacity of the connection of the brace with the stub for fillet welds is very small because, in addition to the longitudinal force, the resulting bending moment at small, effective lengths of fillet welds must be taken into account.

For similar reasons, do not apply this method to the stub of H-beam. In the connection of the channel with the chord, only fillet welds arranged at the webs of those elements are fully effective. In such a case, the capacity of the joint is insufficient.

\subsection{The resistance of the joint}

Typically, the difference in width of webs of members connected in the joint is sufficiently great (approximately $2 \times 50 \mathrm{~mm}$ to $2 \times 70 \mathrm{~mm}$ ), and the spacing between their flanges allows the easy arrangement of fillet welds.

Another geometry for the support joint in which the members overlap each other but do not completely cover because of different widths $\left(b_{p}<b_{f b}\right)$ may be considered in a manner analogous to the joints of the bottom chord. It is necessary to separately assess the resistance of the connection of the brace and the top chord considering Figs. 4 to 9 and to take into consideration relationships relating to the effective lengths of welds, the design cross section areas, eccentricities and values of forces parallel and perpendicular to the stub and corresponding components of stresses in the welds.

In such method of resistance assessing the design of the support joint does not require further detailed interpretation because the symbols and methods of calculation do not change. The only difference is that, looking at the stub as the chord of the $\mathrm{K}$ joint, the brace is directed in the opposite direction. This formally requires the evaluation of signs of stress components in considered lengths of welds, but, practically, there is no effect on the final result of calculating the capacity of such a connection.

However, in the case of the connection of the top chord with the stub, angle $\theta_{i}$ between these members (see Fig. 14 and Fig. 15) is determined as $(\pi / 2-\alpha)$, where $\alpha$ is the angle of the slope of the roof. This angle corresponds formally to the second brace of the bottom chord, but, using given formulas, it should be taken as $\left(\pi-\theta_{i}\right)$. On the other hand, it is necessary to note that the direction 
of force $N_{0}$ is opposite that of force $K_{j}$. Then, examining drawings, the case of the joint of the bottom chord and the calculation formulas do not change. It is necessary to keep in mind that the force in such a considered brace has an opposite direction, which formally affects the signs of stress components in cross sections of welds. The symbols relating to the compression brace should be replaced by the symbols relating to the top chord.

The width of the stub, $b_{f c}=b_{f b}+2 \Delta_{f b}$, where $2 \Delta_{f b}=2,83 a_{w}+15 \mathrm{~mm}$, should enable proper arrangement of the fillet weld along the flanges of the channel. The range of products does not always allow fulfilling this indication, especially in the case of hollow sections with rounded corners. So, instead of fillet welds, groove welds should be applied.

\subsection{The resistance of the members in the joint}

Checking the resistance of the brace and the top chord in the joint with the stub is performed in the manner described with reference to the joint of the bottom chord but changing values of forces, cross-section of members, angles and gaps according to Fig. 14 or Fig. 15.

The resistance of the stub should be checked as follows. The stub is treated as a cantilever fixed in its base, which is usually fastened with four screws in a wall of a building. The reaction of a roof truss is transferred with the negative eccentricity e $\leq 0,5 h_{c}$ (where $h_{c}$ is the height of the cross section of the hollow profile), and, in the case of a channel with flanges reinforced by plates of height $\Delta h_{c}$ and thickness $t_{c}$, the eccentricity is $e \leq e_{z c}$ (where $e_{z c}$ is the distance from the neutral axis of the section assembled with the channel and the plates from the outer edge of the channel web).

Furthermore, the stub is loaded by the reaction of the extreme purlin placed on it directly axially or eccentrically with respect to its neutral axis. Due to the large cross section of the stub and the small length, the assessment of its capacity is carried out in accordance with EN 1993-1-1 [13] in the case of eccentric compression without flexural buckling.

It is desirable that the width of stub $b_{f c}$ is not very different from the width of the top chord $b_{f b}$, so the flanges of the top chord channel are overlaid by the walls or rounded corners of the stub. Then, the wall shear according to EN 1993-1-1 [13] needs to be checked for the web of the stub. The remaining part of the force loading the web of the channel is transmitted to the flange of the stub as a load, which should be modelled as a transverse gusset plate according to Table 7.13 in EN 1993-1-8 [14]. Then, the capacity of this plate is checked using the equation specified in that table.

The capacity of the wall of the stub locally loaded by the brace can be approximately checked as a chord of a truss made of that channel, according to EN 1993-1-8 [14] as was given in relation to the joint of the bottom chord. 


\section{The splice ridge joint}

Fig. 16 shows such a joint with the geometry of connected members, which enables a sufficiently easy arrangement of fillet welds. The shaping of components, as well as their connections, is analogous to that discussed in the case of the support joint. Two thick flange plates, connected using pre-loaded bolts during assembly, are pressed against each other, so that they can be regarded as a reduced stub, which is loaded with the longitudinal forces of the top chord and the brace. Such a reduced K joint is considered only because of its connection zone.

The gap between the flanges of joining members is even greater than in the case of the stub.

Some disadvantages of laying fillet welds may occur during their execution between the webs of members and flange plates. With a large thickness of two flange plates, it is permissible to increase the distance between the webs of the channel above the value of $t_{1}+t_{2}$ to facilitate a good view of the welds. The angle of the connection of the brace with the flange plate is, in this case, typically about $30^{\circ}$ while, in the support joint, it is generally higher. One should be particularly careful when making welds in such angle. Usually, a fillet weld is then converted to a butt weld, but with an unusual shape. To get a weld of sufficient quality, it is placed between the flange plate earlier than the connection of the top chord with the plate.

Checking the resistance of the welds should be carried out as in the case of a support joint. Checking the capacity of the bolted connection is made in accordance with the indications given in EN 1993-1-8 [14]. Although the flange plate is loaded primarily by bearing, transmitted by pre-loading bolts, the need to obtain a minimum flexibility of the K-type joint requires sufficiently thick plates. In the case of a truss span in the range of 20 to $30 \mathrm{~m}$ and a light type load, it a thickness of 16 to $20 \mathrm{~mm}$ is proposed.

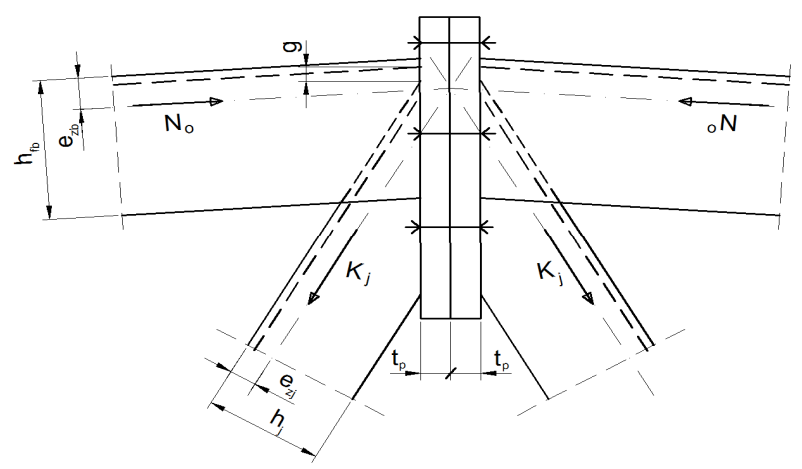

Fig. 16 Splice ridge joint

Rys. 16 Styk kalenicowy wiązara 


\section{The results of the calculated example of the truss}

The procedures and equations presented in the paper were checked by designing a roof truss with a span of $26 \mathrm{~m}$ and a height of $26 \mathrm{~m}$. The top chord was made from the channels UP 360, the bottom chord from the channels U200, and braces and inserts were made from the channels U180 or U120. The resistance of the fillet welds was first evaluated at their maximum thickness, and, after the determination of stresses in the welds using the directional method, the reduction of their thickness was proposed so that the maximum stress in the welds gave a reserve of resistance of about $30 \%$. Such a reserve was considered sufficient in most of the loaded joints. Due to the standardization of the braces to only two sections, the other joints show higher resistance than desired.

As expected, the use of an insert in the joints of the top chord made of a channel of the same size as the cross-section of the braces requires the strengthening of the joint with a relatively thick plate because the web of the insert is too thin to carry out the component forces parallel to the web. This is the only drawback of the designed truss. Performing the fillet welds in other design situations encountered no difficulties since most of the welds were laid with good access to the place of their location. Only the brace of the ridge joint was arranged relative to the flange plate at an angle of $32^{\circ}$.

In trusses with spans smaller than in the analysed project, the insert can be designed from the lengths of rectangular hollow sections by choosing hot rolled products with the same wall width and thickness. In trusses with spans similar to the considered structure, this is not always possible due to the lack of suitable products.

The use of trusses made of channel sections under light roofs and with greater spans is limited to a value not exceeding $30 \mathrm{~m}$ due to the range of products supplied by steelworkers.

\section{Conclusions}

1). Presented design method of roof trusses made of channels concerns evaluation of the joints resistance and their welded connections. It refers to joints that are considered to be almost rigid (with low flexibility).

2). The procedures for assessing the resistance of joints and their welded connections can be used only with sufficiently low flexibility of joints. This is achieved when the gap between the webs of the channel sections used in the joints of the bottom chord and in the support and ridge joints have a value of $g=t_{1}+t_{2}$ or slightly different.

3). The V-shaped trusses with K-type joints have always one joint in the bottom chord where the two braces are compressed. In such a joint the bottom chord should be reinforced with the rib and the braces should be connected with the gap of $g=t_{1}+t_{2}$. 
4). The procedures for calculating the capacity of joints and their welded connections were developed, taking into account the rules concerning the members and joints made of rectangular hollow sections and channels given in EN 1993-1-8 [14].

5). The rules indicated in 4) are the theoretical background of described procedures. It is desirable to confirm them experimentally or numerically.

6). If there is a fear that the joints of the bottom chord or support joints have an inadequate stiffness, until presented rules will be confirmed by research, they should have been stiffened using the ribs or plates designed in their areas.

\section{Bibliography}

[1] ArcerolMittal. Sections and Merchant Bars. Sales Programme (http://www. constructalia.com/english/publications/brochures/sections_and_merchant_bars_ sales_programme\#.VS-YoJM3gmM).

[2] Augustyn J. Welded and spotted joints. Arkady. Warsaw 1987 (in polish).

[3] Bogucki W., Żyburtowicz M. Tables for design of metal structures. Arkady. Warsaw 2008 (in polish).

[4] Bródka J. Examples of errors in design of structures made of hollow sections. Steel Structures. 1999, no. 2 (in polish).

[5] Bródka J., Broniewicz M. Calculation of welded joints of trusses made of rectangular hollow sections. - Steel Structures. 2002, no. 4 (in polish).

[6] Bródka J. Broniewicz M. Design of steel structures according to Eurocodes. PWT. Rzeszow, Poland 2013 (in polish).

[7] Bródka J. Kozłowski A., Ligocki I., Łaguna J., Ślęczka L. Design and calculation of connection and joints in steel structures. Vol. 1, 2nd Edition. PWT. Rzeszow 2013, Poland (in polish).

[8] BS ISO 14346: 2013 Welding-static design procedure for hollow section joints. Recommendations.

[9] Deutcher Stahhlbau-Verband. Stahlbauhandbuch. Band 2: Stahlkonstruktionen. 2 Auflage. Stahlbau-Verlagsgeselschaft. Köln 1985.

[10] Kindmann R., Stracke M. Verbindungen im Stahl- und Verbundbau. Ernst und Sohn. A Wiley Company. Berlin 2003.

[11] Łubiński M., Filipowicz A., Żółtowski W. Metal structures. Part 1. Arkady. Warsaw 2000 (in polish).

[12] EN 1090-2: 2007 Execution of steel structures and aluminium structures. Technical requirements for steel structures.

[13] EN 1993-1-1: 2006 Eurocode 3. Design of steel structures. General rules and rules for buildings.

[14] EN 1993-1-8: 2006 Eurocode 3. Design of steel structures. Design of joints.

[15] EN 1993-1-10: 2007 Eurocode 3: Design of steel structures - Part 1-10: Material toughness and through-thickness properties.

[16] EN 10025: 2007 Hot rolled products of structural steels. Parts 1 to 5.

[17] Rykaluk K.: Steel structures. Bases and members. Dolnośląskie Wydawnictwo Edukacyjne. Wroclaw 2001 (in polish). 
[18] Żmuda J. Bases of design of steel structures. Arkady. Warsaw 1997 (in Polish).

[19] Steel structures of buildings. Design according to the Eurocodes with examples of calculations. Collective work under the direction of M. Giżejowski and J. Ziółko. Arkady. Warsaw 2010 (in polish).

\section{PROJEKTOWANIE KRATOWNIC WYKONANYCH Z CEOWNIKÓW ZGODNIE Z ZASADAMI EUROKODÓW}

\section{Streszczenie}

Niniejszy artykuł prezentuje zagadnienia dotyczące projektowania kratownic wykonanych z ceowników zgodnie z zasadami zawartymi w Eurocodach. Kratownice dachowe wykonane z gorąco walcowanych kształtowników ceowych są projektowane głównie w przypadku średnich rozpiętości i stosunkowo niewielkich obciążeniach. Wykorzystując metodę długości efektywnych zaproponowano metodę projektowania spoin w węzłach kratownic typu K i N. Takie połączenia spawane powinny być projektem na siły osiowej występujące w skratowaniu. Zaproponowano również sposób wyznaczania układów spoin i procedury obliczania długości poszczególnych odcinków. W przypadku węzłów pośrednich pasa górnego, zasugerowano ukształtowanie węzła z wkładką z ceownika do mocowania krzyżulców w celu uzyskania odpowiedniej nośności. Zaprezentowano również rozwiązanie węzła podporowego umożliwiającego odpowiednie rozmieszczenie spoin pachwinowych łączących pas górny z krzyżulcem podporowym z kształtowników zamkniętych kwadratowych lub prostokątnych. Opisane metody umożliwiają projektowanie połączeń spawanych kratownic z kształtowników ceowych. Powyższe zalecenia są przeznaczone do statycznie obciążonych spoin pachwinowych i szerokobruzdowyc.

Słowa kluczowe: konstrukcje stalowe, węzły kratownic typu K i N , długość spoin, nośność elementów 